\title{
First record of the reef manta ray, Mobula alfredi, from the eastern Pacific
}

\author{
Randall Arauz ${ }^{1 *}$ (D) Elpis J. Chávez ${ }^{2}$, E. Mauricio Hoyos-Padilla ${ }^{1,3}$ and Andrea D. Marshall ${ }^{4}$
}

\begin{abstract}
An opportunistic sighting of a reef manta ray (Mobula alfredi) along the northeastern corner of Cocos Island, Costa Rica, represents the first sighting of this species nearly $6000 \mathrm{~km}$ from the nearest confirmed sighting location in the Marquesas Islands and the first record of this species on either side of the American continent. Cocos Island is situated approximately $500 \mathrm{~km}$ away from mainland Costa Rica as well as any other suitable habitat for this species, suggesting the sighted individual may have migrated to this location. The individual was fitted with an acoustic transmitter (V16 Vemco Ltd., Nova Scotia, Canada) which will enable monitoring of its habitat use around the island and potential long-term residency patterns.
\end{abstract}

Keywords: Manta ray, Range extension, Costa Rica, Photo identification, Migration

Understanding the range and distribution of pelagic and highly mobile species, like Mobulid rays, is of critical importance. Most members of this ray group are highly threatened and may face extirpation where targeted in large fisheries (Couturier et al. 2012b; Ward-Paige et al. 2013; Dulvy et al. 2014; Croll et al. 2015). Despite a surge in effort over the last two decades to study manta rays, many key aspects are still poorly understood and require additional investigation (Stewart et al. 2018). For instance, the global distributions of both recognized species, Mobula birostris and Mobula alfredi, have, to a large extent, been inferred or projected from opportunistic sighting records, a few dozen focused studies, fisheries data, historical records and perceived habitat suitability (Kashiwagi et al. 2011; Lawson et al. 2017; Marshall et al. 2018a, 2018b). Further investigation is required to confirm existing distribution information and to fill in the gaps in areas where little to no information is currently available. Presently, $M$. birostris, the more widely distributed species, exhibits a broad, circumglobal distribution in all three of the world's major oceans (Kashiwagi et al. 2011; Lawson et al. 2017; Marshall et al. 2018b). To date there have not been any verified or published records of $M$. alfredi from

\footnotetext{
* Correspondence: rarauz@finsattached.org

${ }^{1}$ Fins Attached Marine Research and Conservation, 19675 Still Glen Drive, Colorado Springs, CO 80908, USA

Full list of author information is available at the end of the article
}

the Atlantic or on either side of the American continent (Lawson et al. 2017). M. alfredi is widely distributed throughout the Indian Ocean, including large populations in isolated island chains like the Maldives and Chagos Archipelagos (Lawson et al. 2017). M. alfredi is also commonly encountered in the West Pacific (Lawson et al. 2017) but published accounts report this species occurring only as far east as Fatu Hiva $\left(10^{\circ} 29_{-} \mathrm{S}, 138^{\circ} 37_{-} \mathrm{W}\right)$ in the Marquesas Islands (Mourier 2012).

M. alfredi appears to display a more resident behavior than $M$. birostris, with a fairly restricted home range for such a capable swimmer. Some studies have suggested that $M$. alfredi's range may be quite small (Kessel et al. 2017). Deakos et al. (2011) reported that despite considerable effort, no matches were found when cross referencing 290 individual manta rays from one study area in Maui, Hawaii and 145 photo-identified individuals in waters off Kona on the Big Island, a transit distance of only $\sim 150 \mathrm{~km}$. Setyawan et al. (2018) recently found that $M$. alfredi tagged in the north of Raja Ampat did not venture to the southern end of the seascape a distance of only $180 \mathrm{~km}$. Other studies have shown that $M$. alfredi can and often do make inter-island movements between neighboring islands up to $450 \mathrm{~km}$ straight-line distance apart (Homma et al. 1999; Kitchen-Wheeler 2008; Germanov and Marshall 2014). However, the longest documented straight-line movements of $M$. alfredi have occurred along continental coastlines, in 

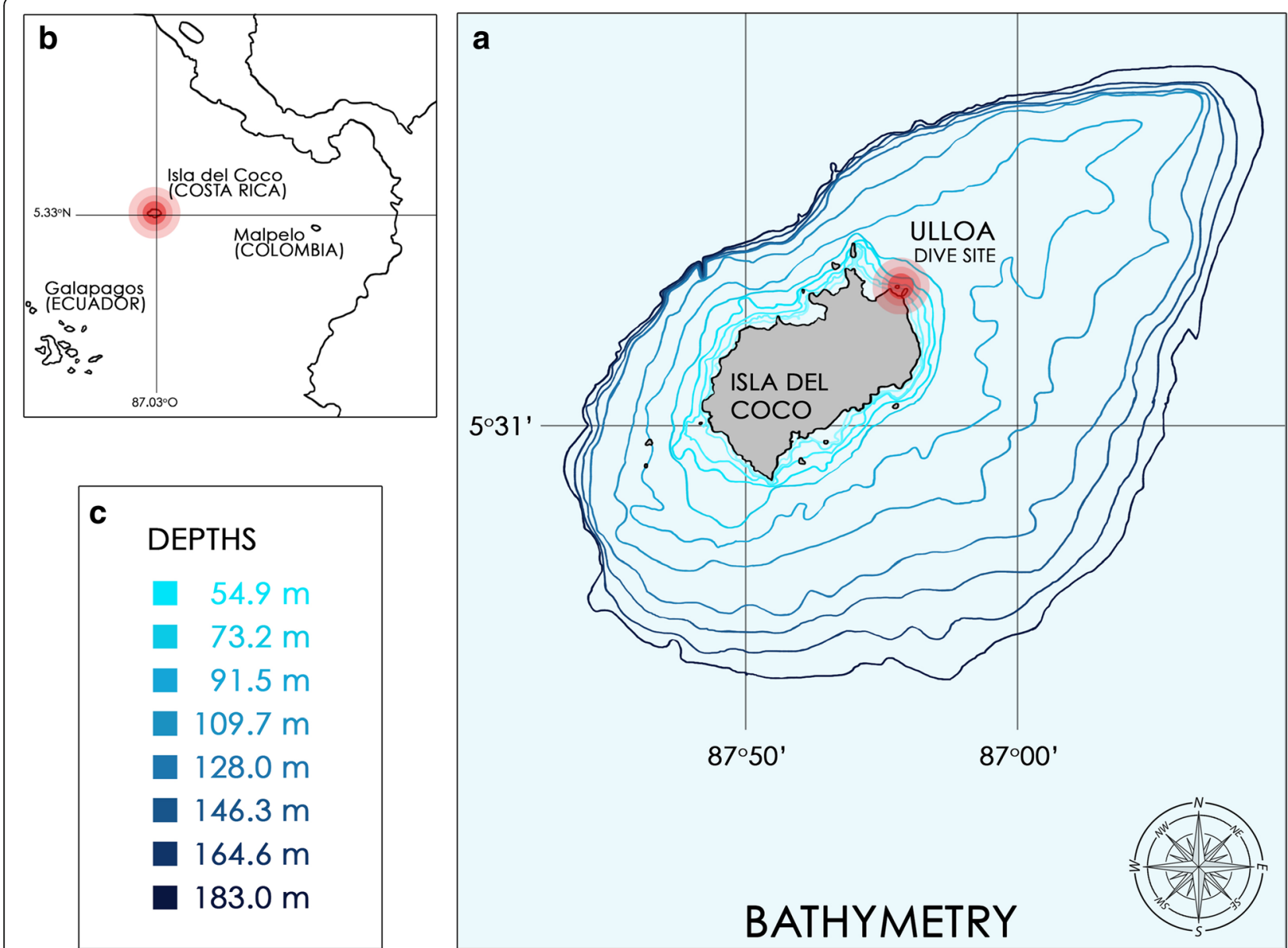

Fig. 1 a Bathymetry map of Cocos Island, Costa Rica, with location of Ulloa dive site, including b location of Cocos Island in the Eastern Tropical Pacific, and $\mathbf{c}$ key to bathymetry map

locations like Australia (650 km in Couturier et al. 2014) and Mozambique (500 $\mathrm{km}$ in Marshall unpublished data). In a recent study of $M$. alfredi in Australia, satellite tracked reef manta rays moved across a latitudinal range of 1035 $\mathrm{km}$ along the northern eastern coast, travelling up to 2441 $\mathrm{km}$ in $118 \mathrm{~d}$ (Jaine et al. 2014) and venturing as far as 520 $\mathrm{km}$ in any one direction from the tagging site. Notably the individual rays tracked in this study occupied both regional shelf and offshore waters swimming up to $155 \mathrm{~km}$ off the continental shelf presumably to forage in deeper waters. Perle (2011) also noted that satellite tagged M. alfredi around the Palmyra Atoll in the Pacific swam offshore but no further than $126 \mathrm{~km}$ from the atoll, suggesting that their dependence on shallow inshore reefs for cleaning may limit their range into open ocean environments. Aplethora of other studies confirm the regular, habitual use of shallow water habitats, particularly cleaning stations, where individuals are cleaned by attending fish while they socialize with conspecifics (Dewar et al. 2008; Deakos et al. 2011; Kitchen-Wheeler et al. 2011; Marshall 2009; Couturier et al. 2018).
Jaine et al. (2014) noted that while M. alfredi moved across wide geographical areas along the eastern Australian coastline, individuals often returned to the area they were tagged. Other telemetry-based studies have demonstrated individual variation in movement patterns but agree that home ranges are relatively restricted and that individuals regularly and repeatedly visit known sites within a larger home range (Dewar et al. 2008; Marshall 2009; van Duinkerken 2010; Kessel et al. 2017; Couturier et al. 2018; Setyawan et al. 2018). Long-term site fidelity has been confirmed and quite commonly reported in dedicated photographic studies of $M$. alfredi as well, with photo identified individuals being seen at the same aggregation areas over short and long time periods (Homma et al. 1999; Kitchen-Wheeler et al. 2011; Marshall et al. 2011; Couturier et al. 2014) providing additional support to the notion that individuals remain within restricted home ranges. The seasonal movements and longer distance migrations that do occur are thought to be related to seasonal shifts in resource use (Dewar 2008; Couturier et al. 2012a; Jaine et al. 2012; Jaine et al. 2014) or 
reproduction, in response to strong seasonal weather patterns such as the monsoon season (Anderson et al. 2011; Setyawan et al. 2018).

On September 5th, 2018 during a scientific research expedition to Cocos Island, Costa Rica, a female manta ray was encountered during a scientific dive around Ulloa, a shallow dive site ( $\sim 14 \mathrm{~m}$ depth) located in the northeast side of the island (Fig. 1). Underwater video shots were taken of the dorsal and ventral coloration patterns of the individual, and an ID photo taken of the unique ventral spot patterning (following Marshall et al. 2011; Marshall and Pierce 2012) to support re-sighting efforts (Fig. 2). Upon reviewing the footage the individual was confirmed to be a reef manta ray (using the key provided in Marshall et al. 2009). The approximate disc width (DW) of this individual was $3.5 \mathrm{~m}$, and appeared to be in the later stages of pregnancy based on the large bulge on its stomach and back (Marshall and Bennett 2010) (Fig. 2d). The individual was close to the bottom swimming slowly against the current with the cephalic lobes fully extended, however it was not feeding at the time. The individual was successfully fitted externally with a V16 (Vemco Ltd., Nova Scotia, Canada) acoustic tag using a pole spear as a part of a larger on-going study of the habitat use of elasmobranchs around the island.

This is the first sighting of $M$. alfredi in the Eastern Pacific, nearly $6000 \mathrm{~km}$ east from the nearest confirmed sighting location in the Marquesas. Despite numerous mobulid-focused research studies occurring from La Paz to Peru, this species has never been recorded along this coast (Lawson et al. 2017). An open-sourced global online manta ray database, Manta Matcher (https://mantamatcher.org), which includes photographic contributions from 'citizen scientists', also has not registered any sightings of this species, despite registers of over 2816 manta rays from this region (Marshall and Holmberg 2018). The Manta Matcher database, which currently holds records of over 9839 individually identified manta rays, was also used to scan globally for a match of this individual with no success (Marshall and Holmberg 2018).

Deep water and sizeable distances between the island chains in the mid-Pacific and the islands and seamounts in the Eastern Pacific presumably present a natural barrier for dispersal of $M$. alfredi. Cocos Island sits offshore to mainland Costa Rica. The nearest land or shallow water habitats are more than $500 \mathrm{~km}$ away in any direction. With no other confirmed sightings of this species in the Eastern Pacific, it is likely that this individual has swum from an aggregation site between the Hawaiian Islands (a distance of over $7596 \mathrm{~km}$ from the closest known aggregation area off Keauhou) and the Marquesas (a distance of over $5984 \mathrm{~km}$ from Fatu Hiva) (Fig. 3). Rate of movement estimates have noted $M$. alfredi can travel between 85 and $95 \mathrm{~km}$ a day straight line distance (van Duinkerken 2010; Jaine et al. 2014), averaging speeds of $\sim 3.5 \mathrm{~km}$ per hour. These estimates suggest that such a long-distance crossing would have taken this individual over two months at a minimum.

While it has not yet been confirmed if the ventral spot patterns on the underside of manta rays are heritable,

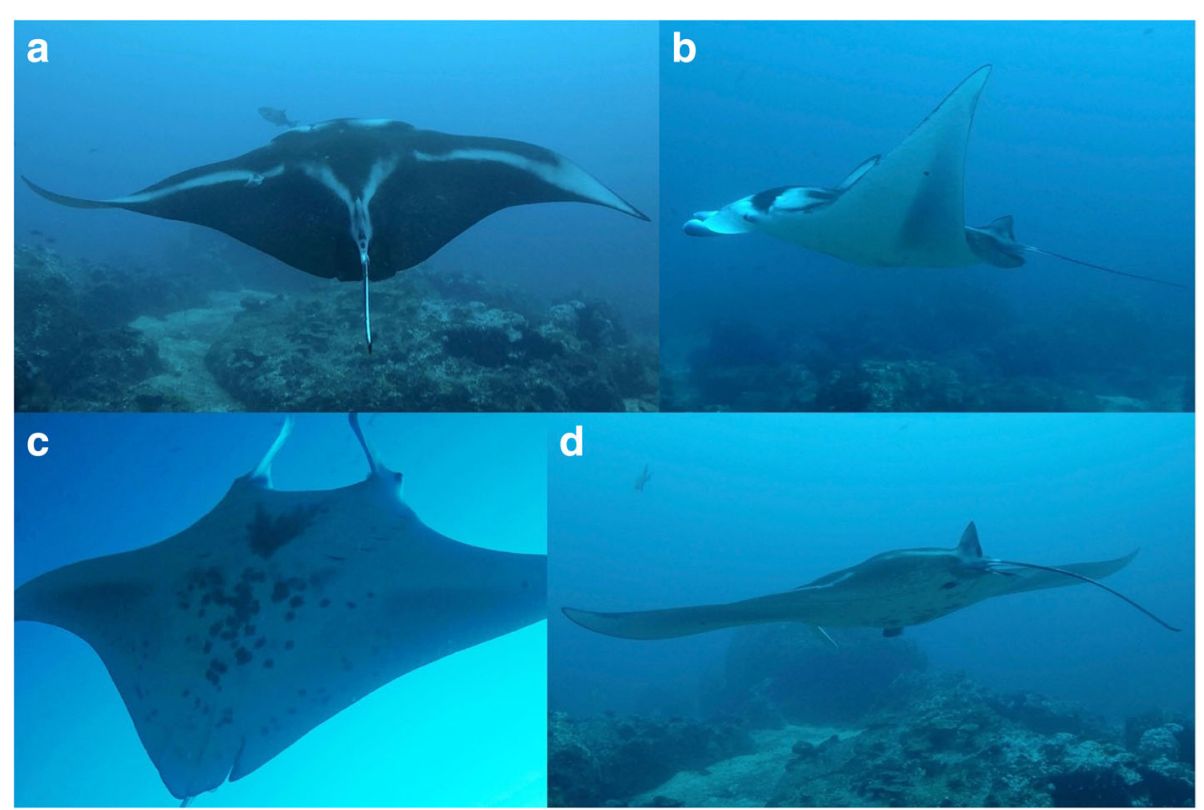

Fig. 2 Still frame grabs from the video taken at the time the individual was sighted, showing a the dorsal colouration, $\mathbf{b}$ the colouration around the face and head, $\mathbf{c}$ the ventral colouration including the unique spot patterning of the individual and $\mathbf{d}$ the bulge on the belly and back indicating the individual was in later stages of a pregnancy 


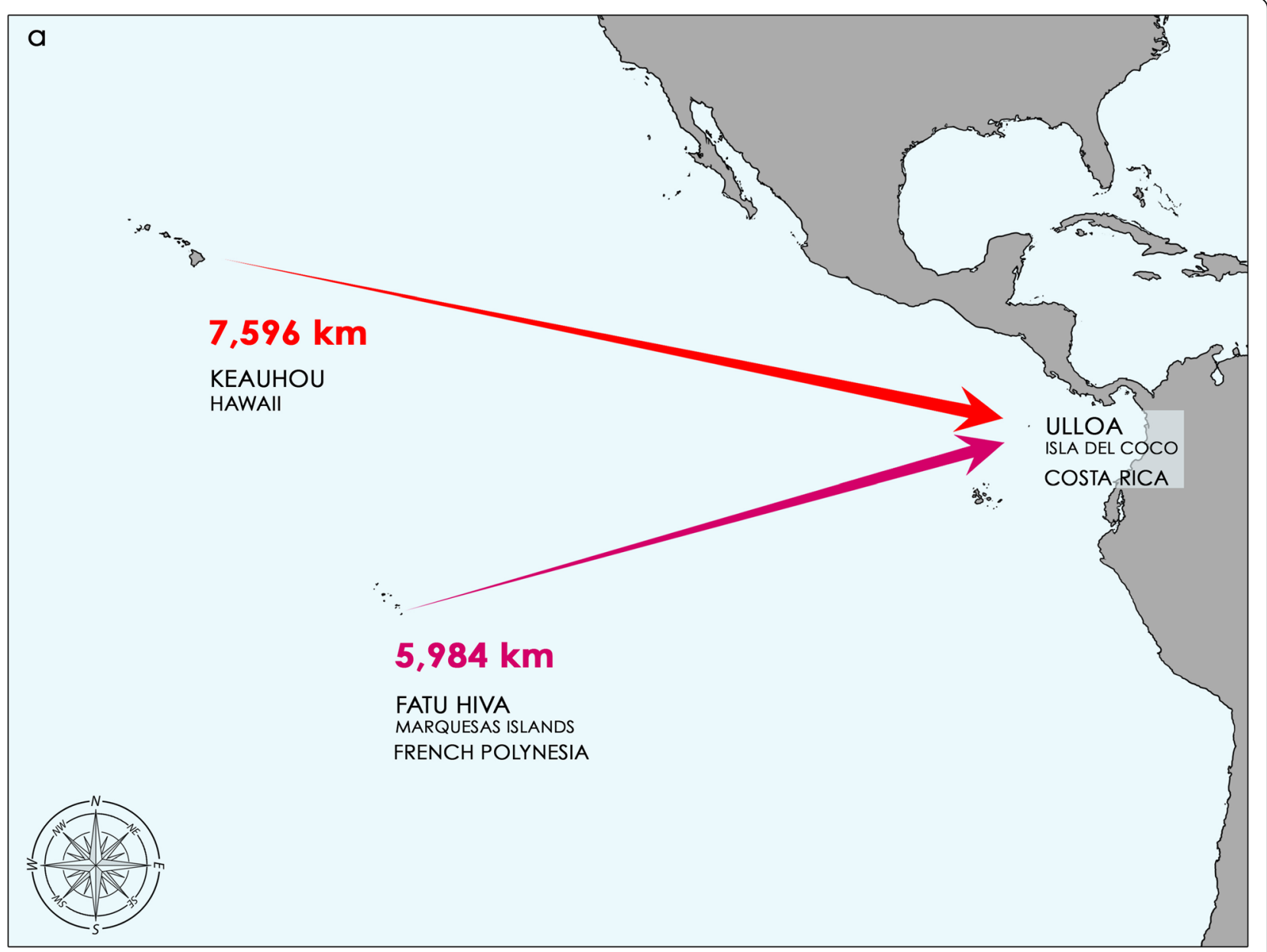

Fig. 3 The straight-line distances and expanse of open water between the two nearest known aggregation areas for M. alfredi in the Pacific Ocean and Ulloa, Cocos Island Costa Rica

global databases appear to show general regional patterns in colouration/pattern types (Marshall and Holmberg 2018; Stevens and Manta 2016). The manta ray sighted off Ulloa at Cocos Island exhibited similar coloration patterns to those seen in both the Hawaiian Island and the Marquesas, which may be further suggestive of its origin.

Manta rays are not commonly sighted at Cocos Islands (White et al. 2015) but when they are encountered S.C.U.B.A. divers report seeing $M$. birostris. Data collected by divemasters over the past 21 years (1992 to 2013) have shown an $89 \%$ decline in relative abundance of this species around the island (Sibaja-Cordero 2008; White et al. 2015). Given that this is not a common aggregation area for manta rays, it is surprising to record the presence of $M$. alfredi at this location. Since the individual was fitted with an acoustic transmitter we will be able to monitor its habitat use and long-term residency at Cocos Island.
The single opportunistic encounter of $M$. alfredi at Cocos Island in the Eastern Pacific does not warrant an extension of the known range of this species. However, while authors cautiously assume that this individual may have unintentionally migrated to this location, we cannot ignore the possibility that small populations of $M$. alfredi may in fact exist in the Eastern Pacific. Major aggregation areas for manta rays are being still actively being discovered. While considerable efforts have been made to identify critical habitats for manta rays in the Eastern Pacific, many areas have still not been comprehensively explored.

This reported encounter does offer tantalizing clues about the way this species may have successfully colonized much of its range. While current research suggests that physical barriers and in particular open expanses of sea typically deter individuals from undertaking regular long-distance migrations, we are now left to consider that $M$. alfredi, under certain circumstances, may occasionally undertake long-distance movements. Is it worth 
noting that other long distance movements by other elasmobranches with even lower ability to conduct long distance migrations have been reported, such as a juvenile male blacktip reef shark (Carcharhinus melanopterus), one of the most common Indo-Pacific reef sharks, reported for the first time in the Eastern Pacific on April 29, 2012 (López-Garro et al. 2012). The early life stage of the individual suggests a pregnant female had given birth near Cocos Island after travelling over 5000 $\mathrm{Km}$ across the Pacific Ocean (López-Garro et al. 2012). In fact, several species of Indo-Pacific elasmobranches have successfully managed to colonize the Eastern Pacific, such as silvertip sharks (Carcharhinus albimarginatus) and whitetip sharks (Triaendon obesus), while other species such as the marbled ray (Taeniura meyeni) which is endemic to Cocos Island and Galapagos Island, remain restricted in either the the Eastern or Western Pacific (Garrison 2005).

As a species, $M$. alfredi is wide spread in the Western Pacific and Indian Oceans with large populations occurring around relatively isolated islands and archipelagos. The successful colonization of these regions through time would have required accidental or purposeful long-range migrations of pregnant individuals to these areas to seed founder populations. Considering their wide-spread occurrence in these oceans, it is likely that these events occur more commonly than expected from their studied behavioral trends, which raises the question as to why colonization attempts by $M$. alfredi in the Eastern Pacific have been unsuccessful, and the species has failed to thrive in this productive region.

\begin{abstract}
Acknowledgements
Authors would like to acknowledge the monumental efforts of Alex Antoniou, CEO of Fins Attached Marine Research and Conservation, to provide a platform such as the marine research vessel M/Y Sharkwater to facilitate research on highly migratory species in the Eastern Pacific. We would also like to thank the professional and dedicated support of $M / Y$ Sharkwater's crew: José Mora Calderón, Marlo Mauricio Sánchez de la Hoz, Jaffers Javier Perez Guillen, Jorge Javier Ruiz Navarro, Pablo Gabriel Delgado Talavera, Gustavo Barrantes Mendoza and Rafael Angel Solano Cambronero. We also thank the following officers of the Cocos Marine Conservation Area (Spanish acronym ACMC), all of whom were instrumental in obtaining relevant research permits in a professional and timely fashion: Marco Araya, Esteban Herrera, Johanning Corrales Vega, and Braulio Navarro Cabezas. Carlos Manuel Rodríguez, Minister of Environment of Costa Rica, provided fundamental support for the successful development of this project when it was most critically needed. Thanks for that! Special thanks to Denver Divers for their collaboration in one of the 2018 Cocos Island research expeditions.
\end{abstract}

\section{Funding}

Scientific expeditions to Cocos Island in 2018 were funded by Fins Attached Marine Research and Conservation, with support from Conservation International - Costa Rica, the Friends of Cocos Island Foundation (Spanish acronym FAICO), the Whitley Fund for Nature, the PEW Fellowship in Marine Conservation, and the Sandler Foundation.

\section{Availability of data and materials}

The datasets analyzed during the current study are available in the WildMe Wildbook Manta Matcher online database (https://mantamatcher.org) and are therefore freely available. The supporting video taken from the encounter is available for viewing at: https://drive.google.com/ open?id=1jbg_e7wpZW5mY-GG0TiLc5P-80wme58k

\section{Authors' contributions}

ADM wrote the manuscript, EMHP assisted the fieldwork and conceived, wrote and edited the manuscript, RA conducts the long term development of the broader highly migratory species tagging project in Cocos Island, and in this particular case co-conducted the fieldwork and edited the manuscript, EJC conducted the field work and edited the manuscript. All authors read and approved the final manuscript.

\section{Ethics approval}

Not Applicable. However, Research Permits were obtained from the Cocos Marine Conservation Area (Spanish acronym ACMC) of the National System of Protected Areas (Spanish acronym SINAC) of Costa Rica, No. 2018-I-ACMC11 and No. 17-2018-I-ACMC, a process during which ethics issues are considered.

\section{Consent for publication}

Not Applicable.

Competing interests

The authors declare that they have no competing interests.

\section{Publisher's Note}

Springer Nature remains neutral with regard to jurisdictional claims in published maps and institutional affiliations.

\section{Author details}

${ }^{1}$ Fins Attached Marine Research and Conservation, 19675 Still Glen Drive, Colorado Springs, CO 80908, USA. ${ }^{2}$ Centro de Rescate de Especies Marinas Amenazadas (CREMA), Calle 114, 1.5 km N, Barva, Heredia, C.P 40201, Costa Rica. ${ }^{3}$ Pelagios Kakunjá, Sinaloa 1540, La Paz, B.C.S C.P. 23070, México. ${ }^{4}$ Marine Megafauna Foundation, 11260 Donner Pass Road Truckee, California, USA.

Received: 7 December 2018 Accepted: 6 February 2019

Published online: 20 March 2019

\section{References}

Anderson RC, Adam MS, Goes JI. From monsoons to mantas: seasonal distribution of Manta alfredi in the Maldives. Fish Oceanogr. 2011;20(2):10413. https://doi.org/10.1111/j.1365-2419.2011.00571.x.

Couturier LIE, Dudgeon CL, Pollock KH, Jaine FRA, Bennett MB, Townsend KA, Weeks SJ, Richardson AJ. Population dynamics of the reef manta ray Manta alfredi in eastern Australia. Coral Reefs. 2014. https://doi.org/10.1007/s0033801401126-5.

Couturier LIE, Jaine FRA, Townsend KA, Weeks SJ, Richardson AJ, Bennett MB. Distribution, site affinity and regional movements of the manta ray, Manta alfredi (Kreft, 1868), along the east coast of Australia. Mar Freshw Res. 2012a; 62:628-37. https://doi.org/10.1071/MF10148.

Couturier LIE, Marshall AD, Jaine FRA, Kashiwagi T, Pierce SJ, Richardson AJ, Townsend KA, Weeks SJ, Bennett MB. Biology, ecology and conservation of the Mobulidae. J Fish Biol. 2012b;80:1075-119.

Couturier LIE, Newman P, Jaine FRA, Bennett MB, Venables WN, Cagua EF, Townsend KA, Weeks SJ, Richardson AJ. Variation in occupancy and habitat use of Mobula alfredi at a major aggregation site. Mar Ecol Prog Ser. 2018; 599:125-45. https://doi.org/10.3354/meps12610.

Croll D, Dewar H, Dulvy N, Fernando D, Francis M, Galvan-Magana F, Hall M, Heinrichs S, Marshall A, McCauley D, Newton K, Notarbartolo-di-Sciara G, O'Malley M, O'Sullivan J, Poortviet M, Roman M, Stevens G, Tershy B, White W. Vulnerabilities and fisheries impacts: the uncertain future of Manta and devil rays. Aquat Conserv. 2015. https://doi.org/10.1002/aqc.2591.

Deakos MH, Baker JD, Bejder L. Characteristics of a manta ray Manta alfredi population off Maui, Hawaii and implications for management. Mar Ecol Prog Ser. 2011;429:245-60. https://doi.org/10.3354/meps09085.

Dewar H, Mous P, Domeier M, Muljadi A, Pet J, Whitty J. Movements and site fidelity of the giant manta ray, Manta birostris, in the komodo Marine Park. Indonesia Mar Biol. 2008. https://doi.org/10.1007/s00227-008-0988-x. 
Dulvy NK, Pardo SA, Simpfendorfer CA, Carlson JK. Diagnosing the dangerous demography of manta rays using life history theory. Peer J. 2014;2. https:// doi.org/10.7717/peerj.400.

Garrison G. Peces de la Isla del Coco, 2 Edn. Costa Rica: INBio. Santo Domingo de Heredia; 2005.

Germanov E, Marshall A. Running the gauntlet: regional movement patterns of Manta alfredi through a complex of parks and fisheries. PLoS One. 2014;9(10):e115660.

Homma K, Maruyama T, Itoh T, Ishihara H, Uchida S. Biology of the manta ray, Manta birostris Walbaum, in the indo- Pacific. In: Seret B, Sire JY, editors Indo-Pacific fish biology: proceedings of the fifth international conference on indo-Pacific fishes, Noumea 1997. Paris: Ichthyological Society of France; 1999. p. 209-16.

Jaine FRA, Couturier LIE, Weeks SJ, Townsend KA, Bennett MB, Fiora K, Richardson AJ. When giants turn up: sighting trends, environmental influences and habitat use of the manta ray Manta alfredi at a coral reef. PLoS One. 2012; 7(10):e46170. https://doi.org/10.1371/journal.pone.0046170.

Jaine FRA, Rohner C, Weeks SJ, Couturier LIE, Bennett MB, Townsend KA, Richardson AJ. Movement and habiat use of reef manta rays off eastern Australia offshore excursions, deep diving and eddy affinity. Mar Ecol Prog Ser. 2014;510:73-86 https://doi.org/10.3354/meps10910.

Kashiwagi T, Marshall AD, Bennett MB, Ovenden JR. Habitat segregation and mosaic sympatry of the two species of manta ray in the Indian and pacific Oceans: Manta alfredi and M. birostris. Mar Biodivers Rec. 2011;4:e53. https:// doi.org/10.1017/S1755267211000479

Kessel ST, Elamin NA, Yurkowski DJ, Chechchak T, Walter RP, Klaus R, Hill G, Hussey NE. Conservation of reef manta rays (Manta alfredi) in a UNESCO world Herritage site: large-scale island development or sustainable tourism? PLoS One. 2017;12(10):e0185419. https://doi.org/10.1371/journal.pone.0185419.

Kitchen-Wheeler AM. Migration behaviour of the giant manta (Manta birostris) in the central Maldives atolls. In: Donnelly MA, editor. Joint Meeting of Ichthyologists and Herpetologists. Montreal; 2008.

Kitchen-Wheeler AM, Ari C, Edwards AJ. Population estimates of Alfred mantas (Manta alfredi) in the Central Maldives atolls: north male. Ari and Baa Environ Biol Fish. 2011; https://doi.org/10.1007/s10641-011-9950-8.

Lawson JM, Fordham SV, O'Malley MP, Davidson LNK, Walls RHL, Heupel MR, Stevens G, Fernando D, Budziak A, Simpfendorfer CA, Ender I, Francis MP, Notarbartolo di Sciara G, Dulvy NK. Sympathy for the devil: a conservation strategy for devil and manta rays. PeerJ. 2017;5:e3027. https://doi.org/10. 7717/peerj.3027.

López-Garro A, Zanella I, Golfín-Duarte G, Pérez-Montero M. First record of the blacktip reef shark Carcharhinus melanopterus (Carcharhiniformes; Carcharhinidae) from the Tropical Eastern Pacific. Revista de Biologia Tropical. 2012;60(A00101s1):275-8

Marshall A, Bennett MB, Kodja G, Hinojosa-Alvarez S, Galvan-Magana F, Harding M, Stevens G, Kashiwagi T. Mobula birostris The IUCN Red List of Threatened Species 2018 (amended version of 2011 assessment). 2018b. e. T198921A126669349. https://doi.org/10.2305/IUCN.UK.2018-1.RLTS. T198921A126669349.en. Downloaded on 31 October 2018.

Marshall A, Kashiwagi T, Bennett MB, Deakos M, Stevens G, McGregor F, Clark T, Ishihara H. Sato K. Mobula alfredi The IUCN Red List of Threatened Species 2018 (amended version of 2011 assessment). 2018a. e.T195459A126665723. https://doi.org/10.2305/IUCN.UK.2011-2.RLTS.T195459A126665723.en. Downloaded on 31 October 2018.

Marshall AD. Biology and population ecology of Manta birostris in southern Mozambique, PhD Thesis. Australia: University of Queensland; 2009.

Marshall AD, Bennett MB. Reproductive ecology of the reef manta ray (Manta alfredi) in southern Mozambique. J Fish Biol. 2010;77:169-90.

Marshall AD, Compagno L, Bennett MB. Redescription of genus Manta with resurrection of Manta alfredi (Krefft,1868) (Chondrichthyes; Myliobatoidei; Mobulidae). Zootaxa. 2009;2301:1-28.

Marshall AD, Dudgeon CL, Bennett MB. Size and structure of a photographically identified population of reef manta ray (Manta alfredi) in southern Mozambique. Mar Biol. 2011. https://doi.org/10.1007/s00227-011-1634-6.

Marshall AD, Holmberg J. Manta Matcher Photo-identification Library. 2018. https://mantamatcher.org. Accessed 22 Oct 2018.

Marshall AD, Pierce SJ. The use and abuse of photographic identification in sharks and rays. J Fish Biol. 2012;80:1361-79.

Mourier J. Manta rays in the Marquesas Islands: first record of Manta birostris in French Polynesia and most easterly location of Manta alfredi in the Pacific Ocean, with notes on their distribution. J Fish Biol. 2012;81:2053-8. https:// doi.org/10.1111/j.1095-8649.2012.03449.x.
Perle CR. Movements and migrations of manta rays, pacific blue fin tuna and white sharks: observations and insights at the intersection of life history strategy and marine ecosystem structure, PhD Thesis. USA: Stanford University; 2011.

Setyawan E, Sianipar AB, Erdmann MV, Fischer AM, Haddy JA, Beale CS, Lewis SA, Mambrasar R. Site fiedelity and movement patterns if reef manta rays (Mobula alfredi: Mobulidae) using passive acoustic telemetry in northern Raja Ampat, Indonesia. Nat Conserv Res. 2018;3(4). https://doi.org/10.24189/ncr. 2018.043.

Sibaja-Cordero JA. Tendencias espacio-temporales de los avistamientos de fauna marina en los buceos turísticos (Isla del Coco, Costa Rica). Rev Biol Trop. 2008:56:113-32.

Stevens GMW, Manta PT. The secret life of devil rays. Geneva: Save Our Seas Foundation; 2016.

Stewart J, Jaine FRA, Armstrong A, Armstrong A, Bennett MB, Burgess K, Couturier LIE, Croll D, Cronin M, Deakos M, Dudgeon C, Fernando D, Froman N, Germanov E, Hall M, Hinojosa-Alvarez S, Hosegood J, Kashiwagi T, Laglbauer B, Lezama-Ochoa N, Marshall AD, McGregor F, Notobartolo di Sciara G, Palacios M, Peel L, Richardson AJ, Rubin R, Townsend K, Venables S, Stevens $S$. Research priorities to support effective manta and devil ray conservation. Front Mar Sci. 2018;5:314. https://doi.org/10.3389/fmars.2018.00314.

van Duinkerken D. Movements and site fidelity of the reef manta ray, Manta alfredi, along the coast of southern Mozambique, MSc Thesis. The Netherlands: Utrecht University; 2010.

Ward-Paige CA, Davis B, Worm B. Global population trends and human use patterns of Manta and Mobula rays. PLoS One. 2013;8(9):e74835. https://doi. org/10.1371/journal.pone.0074835.

White ER, Myers MC, Flemming JM, Baum JK. Shifting elasmobranch community assemblage at Cocos Island - as isolated marine protected area. Conserv Biol. 2015;29(4):1186-97. https://doi.org/10.1111/cobi.12478.

\section{Ready to submit your research? Choose BMC and benefit from:}

- fast, convenient online submission

- thorough peer review by experienced researchers in your field

- rapid publication on acceptance

- support for research data, including large and complex data types

- gold Open Access which fosters wider collaboration and increased citations

- maximum visibility for your research: over 100M website views per year

At BMC, research is always in progress.

Learn more biomedcentral.com/submissions 